\title{
Rhenium volatilization in waste glasses
}

Kai Xu ${ }^{a}$, David A. Pierce ${ }^{a}$, Pavel R. Hrma ${ }^{a,}$, Michael J. Schweiger ${ }^{\mathrm{a}}$, and Albert A. Kruger $^{\mathrm{b}}$

${ }^{a}$ Pacific Northwest National Laboratory, Richland, WA 99352, USA

${ }^{b}$ U.S. Department of Energy, Office of River Protection, Richland, WA 99352, USA

\begin{abstract}
We investigated volatilization of rhenium (Re), sulfur, cesium, and iodine during the course of conversion of high-level waste melter feed to glass and compared the results for Re volatilization with those in low-activity waste borosilicate glasses. Whereas Re did not volatilize from high-level waste feed heated at $5 \mathrm{~K} \mathrm{~min}^{-1}$ until $1000^{\circ} \mathrm{C}$, it began to volatilize from lowactivity waste borosilicate glass feeds at $\sim 600^{\circ} \mathrm{C}$, a temperature $\sim 20{ }^{\circ} \mathrm{C}$ below the onset temperature of evaporation from pure $\mathrm{KReO}_{4}$. Below $800^{\circ} \mathrm{C}$, perrhenate evaporation in lowactivity waste melter feeds was enhanced by vigorous foaming and generation of gases from molten salts as they reacted with the glass-forming constituents. At high temperatures, when the glass-forming phase was consolidated, perrhenates were transported to the top surface of glass melt in bubbles, typically together with sulfates and halides. Based on the results of this study (to be considered preliminary at this stage), the high-level waste glass with less foaming and salts appears a promising medium for technetium immobilization.
\end{abstract}

Keywords: Rhenium; Technetium; Volatilization; Waste glass.

\footnotetext{
* Corresponding author. Address: 902 Battelle Boulevard, Richland, WA 99352, United States. Tel.: 5093724581.

E-mail address: pavel.hrma@pnnl.gov (P. Hrma). 


\section{Introduction}

Technetium-99 $\left({ }^{99} \mathrm{Tc}\right)$ is a radioisotope of Tc which decays with a long half-life $\left(2.1 \times 10^{5}\right.$ years) to stable ruthenium-99, emitting beta particles. It has a high fission yield ( 6\%), thus producing a large fraction of the long-lived radiation emission of nuclear waste [1]. In addition, ${ }^{99} \mathrm{Tc}$ is highly mobile in subsurface environments [2,3] and volatile at elevated temperatures [4]. Over $1.28 \times 10^{3} \mathrm{TBq}$ of ${ }^{99} \mathrm{Tc}(>1900 \mathrm{~kg})$ was produced at the Hanford Site during nuclear fuel reprocessing for plutonium production between 1944 and 1989 , of which $\sim 9.8 \times 10^{2} \mathrm{TBq}(\sim 1560$ $\mathrm{kg}$ ) survives in 177 underground tanks of nuclear waste [5]. Hanford Tank Waste Treatment and Immobilization Plant, which is currently under construction, will separate tank waste into highlevel waste (HLW) and low-activity waste (LAW) and immobilize both into durable borosilicate glasses. Over $90 \%$ of the ${ }^{99}$ Tc will be disposed in LAW glass at the Hanford Site in the Integrated Disposal Facility, where ${ }^{99} \mathrm{Tc}$, though at a concentration below 0.001 mass $\%$, will be the primary dose contributor over the period of tens of thousands of years $[4,5]$.

The immobilization of Tc, and its nonradioactive surrogate rhenium $(\mathrm{Re})$, has been a subject of a vast body of literature [6-14]. Unfortunately, a substantial fraction of Tc escapes with the off-gas during vitrification [15-18]. Since the Tc solubility in a typical LAW glass is $\sim 0.2$ mass $\%$ [19] and the Re solubility is $\sim 0.3$ mass $\%$ [20], the solubility should not be a limiting factor for Tc/Re retention during melting. However, the Catholic University of America reported up to $\sim 80 \%$ Re and Tc losses from small-scale melters vitrifying simulated LAW feeds [16-18].

Various options have been considered for the immobilization of the Tc removed from off-gas. One is to extract the Tc from the off-gas condensates and add it to HLW melter feed either in the form of pertechnetate or in the form of durable minerals, such as spinel or sodalite [21-23]. In this work, we pursued the option of adding potassium perrhenate (a nonradioactive 
surrogate for pertechnetate) to a HLW melter feed at a relatively high concentration of $\sim 1$ mass $\%$ Re in the glass.

To understand Re volatility from a high-alumina HLW melter feed in comparison with other volatile elements (S, Cs, and I), we measured losses of these elements during the course of conversion to glass by heating the feed at $5 \mathrm{~K} \mathrm{~min}^{-1}$ and found that Re began to volatilize at temperatures above $\sim 1000^{\circ} \mathrm{C}$. An earlier volatilization of Re was observed by Jin et al. from LAW borosilicate melter feeds $[24,25]$. We attributed these differences to the differences in the content and composition of oxyionic salts in the melter feeds, which induce different levels of foaming. Also, we confirmed as highly plausible the long-suspected transportation of $\operatorname{Re}$ in bubbles to the top surface of melt [26], especially for feeds containing sulfate. Finally, results reported on LAW phosphate glasses by Day et al. [6] indicate other curious aspects of Re incorporation in glass structure.

\section{Volatilization of Re, Cs, S, and I from HLW borosilicate glass}

Volatilization of Re, Cs, S, and I was determined using a high-alumina HLW melter feed (Table 1) heated to a set of target temperatures. The feed was spiked with Re, Cs, and I added as $\mathrm{KReO}_{4}, \mathrm{Cs}_{2} \mathrm{CO}_{3}$ and $\mathrm{NaI} ; \mathrm{S}$ was added as sulfate, a regular component of the waste (and, as we discovered afterward, also as an impurity in the iron source). The feed was prepared as described by Schweiger et al. [27]. Samples of dried slurry feed $(\sim 5 \mathrm{~g})$ were heated in open $1.5-\mathrm{cm} \mathrm{Pt}$ square crucibles at $5 \mathrm{~K} \mathrm{~min}^{-1}$ from room temperature to test temperatures (300 to $1200^{\circ} \mathrm{C}$ in $100^{\circ} \mathrm{C}$ intervals) from which they were quenched in the air. After obtaining the mass loss, samples were analyzed with the inductively coupled plasma atomic emission spectroscopy (ICPAES). 
The elemental retention ratio was computed using three alternative methods. First, the $i$ th element retention ratio, $R_{i}$, where $i$ stands for $\mathrm{Re}, \mathrm{Cs}$, I and $\mathrm{S}$, was defined as a fraction of $i$-th element mass retained in the heat-treated sample and expressed by the formula

$$
R_{i T}=F_{T} \frac{c_{i T}}{c_{i 0}}
$$

where, $F_{T}$ is the sample mass to original mass ratio $\left(F_{T}=m_{T} / m_{0}\right.$, where $m$ is the sample mass $), c_{i}$ is the $i$-th element mass fraction, and subscripts 0 and $T$ stand for the sample before and after the heat treatment to temperature $(T)$, respectively. Here, $c_{i T}$ was determined by ICP-AES, $c_{i 0}$ was calculated based on the batch sheet shown in Table 1 , and $F_{T}$ values were measured for samples heat treated to each test temperature (Fig. 1).

Second, the fraction of $i$-th component mass retained in the sample, can alternatively be expressed as

$$
R_{i j T}=F_{j T} \frac{c_{i T}}{c_{i 0}}
$$

where $F_{j T}=c_{j 0} / c_{j T}$. Here the subscript $j$ stands for the $j$-th nonvolatile element, such as $\mathrm{Al}, \mathrm{Zr}$, or Si. Based on the $j$-th nonvolatile element mass balance, $c_{j 0} m_{0}=c_{j T} m_{T}$, we have $F_{j T}=F_{T}$ and thus $R_{i j T}=R_{i T}$. Accordingly,

$$
R_{i j T}=\frac{c_{j 0} c_{i T}}{c_{i 0} c_{j T}}
$$

The difference between $R_{i T}$ and $R_{i j T}$ is that whereas the $R_{i T}$ values are based on the mass change of samples, the $R_{i j T}$ values are solely based on analytical ICP-AES data, and thus free of possible errors in the determination of heat-treated sample mass.

Fig. 2 displays retentions of $\mathrm{Re}, \mathrm{Cs}$, and $\mathrm{S}$, calculated using Eqs. 1 and $2 \mathrm{~b}$ with $j \equiv \mathrm{Al}$ as a nonvolatile element showing excellent agreement between the retention values as determined by 
the two methods (the standard deviation is 0.016). As Fig. 2c shows, the $\mathrm{S}$ fraction is significantly larger than one. As we learned afterward, this deviation was caused by S impurity in the $\mathrm{Fe}(\mathrm{OH})_{3}$ slurry used as the Fe source.

All three elements (Re, Cs, and S) remained almost fully retained up to $1000^{\circ} \mathrm{C}$ when they began to increasingly volatilize. For the temperature interval $300^{\circ} \mathrm{C} \leq T \leq 1000^{\circ} \mathrm{C}$, the average $c_{i}$ values were $c_{\mathrm{Re}, \text { ave }}=0.0075 \pm 0.0002, c_{\mathrm{Cs}, \text { ave }}=0.0021 \pm 0.00004$, and $c_{\mathrm{S} \text {, ave }}=$ $0.0007 \pm 0.00002$. This allowed us to define a third measure for volatile component retention as

$$
R_{i T, a v e}=F_{T} \frac{c_{i T}}{c_{i, a v e}}
$$

Fig. 2 includes $R_{i T \text {,ave }}$ values for Re, Cs, and S. As Fig. 2c indicates, $R_{S, \text { Tave }}$ eliminates the persistent deviation of $\mathrm{S}$ retention caused by the $\mathrm{S}$ impurity $\left[\sim 0.2 \%\right.$ per $\mathrm{Fe}(\mathrm{OH})_{3}$ by back calculation] in the Fe source.

At $T=1200^{\circ} \mathrm{C}$, the loss of Re reached $\sim 40 \%$ and that of $\mathrm{S} \sim 25 \%$ whereas, remarkably, only $10 \%$ of Cs evaporated from the feed. Fig. 3 clearly demonstrates that Re volatilized from the melt more rapidly than either Cs or S. As Fig. 4 illustrates, no significant losses of other potentially volatile elements $(\mathrm{Na}, \mathrm{K}$, and $\mathrm{Li})$ were detected.

Whereas $\mathrm{Re}, \mathrm{Cs}$, and S appreciably volatilized only after temperature exceeded $1000^{\circ} \mathrm{C}, \mathrm{I}$ was virtually gone by $1000^{\circ} \mathrm{C}$. As Fig. 5 shows, most of the I ( 80\%) was lost by $300^{\circ} \mathrm{C}$. According to Schutte and Whitesides [28], I can volatilize as $\mathrm{HI}$ by the reaction $\mathrm{MI}+\mathrm{HOH} \rightarrow$ $\mathrm{HI} \uparrow+\mathrm{MOH}$, where $\mathrm{M}$ is an alkali metal. This reaction probably occurred during feed slurry drying and continued during dry feed heating as long as chemically bonded or physically dissolved water was present [29]. 


\section{Re volatilization from other types of glasses}

To elucidate the cause of the relatively low volatilization losses of Re and the relatively high temperature at which these losses occurred, we compare in Section 3.1 our results with results for LAW glasses obtained by Jin et al. [24,25]. Though no similar study was performed on phosphate glasses, in Section 3.2 we review responses of Re, Cs, and S to melt bubbling reported by Day et al. [6]. Section 3.3 presents data on evaporation of pure $\mathrm{KReO}_{4}$, and Section 3.4 compares expansion curves of HLW and LAW waste feeds. Sections 3.1 to 3.4 only describe the test procedures and the main results. Attempts to understand the mechanisms of Re volatilization from different types of melter feeds are postponed to Section 4.

\subsection{Re losses from LAW borosilicate glass}

Jin et al. [24,25] investigated Re partitioning in two typical simulant tank waste feeds, AZ-102 and AN-102 containing perrhenate equivalent to $8.1 \mathrm{ppm}$ Re in each glass. They deliberately selected feeds with substantially different sulfate-to-nitrate/nitrite ratios. Table 2 lists the compositions of AZ-102 and AN-102 feed batches and glasses. The feeds were prepared as dried slurries and $~ 20$-g samples were heat treated in open Pt crucibles (5-cm inner diameter) at $5 \mathrm{~K} \mathrm{~min}^{-1}$ from room temperature to test temperatures of 600 to $1100^{\circ} \mathrm{C}$ in $100^{\circ} \mathrm{C}$ intervals. To assess the content of water-soluble salts and the early borate melt, samples were leached in water at $25^{\circ} \mathrm{C}$ and $80^{\circ} \mathrm{C}$. Solutions and solids were analyzed with ICP-AES. Ignoring the tiny fraction of Re lost below $600^{\circ} \mathrm{C}$ [24]., we computed retention ratios using Eq. (1) with the $600^{\circ} \mathrm{C}$ concentration values substituted for $c_{i 0}$. Their $R_{i T}$ values, displayed in Fig. 6 for Re and $\mathrm{S}$ as functions of temperature, show that Re is lost at a slower rate from the high-sulfate, low-nitrate AZ-102 feed than from the low-sulfate, high-nitrate $\mathrm{AN}-102$ feed, retaining at $1100^{\circ} \mathrm{C} \sim 65 \% \operatorname{Re}$ 
from AZ-102 and $\sim 40 \%$ Re from AN-102. In both melts, the $\mathrm{S}$ fraction decreased somewhat initially but changed little above $700^{\circ} \mathrm{C}$ except for a decrease from $\mathrm{AZ}-102$ feed above $1000^{\circ} \mathrm{C}$.

\subsection{Re loss from LAW iron phosphate glass with bubbling}

Iron phosphate glasses melt at a relatively low temperature and dissolve significant fractions of components, such as heavy metals, which are troublesome in borosilicate glass [30,31]. Day et al. [6] melted dry batches (Table 3) of the high-sulfate AZ-102 feed in an open silica crucible $\left(6.35-\mathrm{cm}\right.$ inner diameter) at $1050^{\circ} \mathrm{C}$ for $1 \mathrm{~h}$ to yield $300 \mathrm{~g}$ glass. To investigate the effect of melt bubbling on Re, S, and Cs volatility, they bubbled the melt with dry air at a rate of 0.1 to $0.2 \mathrm{~L} / \mathrm{min}$ for up to $5 \mathrm{~h}$. Concentrations of $\mathrm{SO}_{3}, \mathrm{Re}_{2} \mathrm{O}_{7}$ and $\mathrm{Cs}_{2} \mathrm{O}$ in quenched glasses were measured by X-ray fluorescence (XRF); $\mathrm{SO}_{3}$ concentration was also measured with ICP-AES.

As Figs. $7 \mathrm{a}$ and $\mathrm{b}$ show, Re and $\mathrm{S}$ were escaping from the melts with increasing time of bubbling, following an exponential function $c=c_{1}+\left(c_{2}-c_{1}\right) \exp \left(-t / t_{0}\right)$, where $t$ is the bubbling time, $c$ is the species $\left(\operatorname{Re}_{2} \mathrm{O}_{7}\right.$ or $\left.\mathrm{SO}_{3}\right)$ fraction, $c_{1}$ is the asymptotical residual fraction, $c_{2}$ is the initial fraction, and $t_{0}$ is the time constant. For Re, $c_{1}=46.8 \mathrm{ppm}, c_{2}=214.1 \mathrm{ppm}$, and $t_{0}=2.39 \mathrm{~h}$, indicating that $\sim 15 \%$ of Re tends to resist removal by bubbling, provided that the $c(t)$ function can be extrapolated. Surprisingly, $c_{1}=0.00, c_{2}=0.04$, and $t_{0}=2.87 \mathrm{~h}$ for $\mathrm{SO}_{3}$, which indicates that prolonged bubbling would potentially remove nearly all sulfate from the melt. Contrary to these results, no systematic loss of Cs was observed even after $4 \mathrm{~h}$ bubbling (Fig. 7c).

\subsection{Evaporation of pure $\mathrm{KReO}_{4}$}

Pure $\mathrm{KReO}_{4}(0.4 \mathrm{~g})$ was heated in open porcelain crucibles $(2.5-\mathrm{cm}$ inner diameter) at $5 \mathrm{~K} \mathrm{~min}^{-1}$ to determine the loss by volatilization at several temperatures up to $1100^{\circ} \mathrm{C}$ as shown in Fig. 8. Detectable evaporation was observed at $900^{\circ} \mathrm{C}$, and the melt fully vaporized by $1100^{\circ} \mathrm{C}$ (Fig. 8). 


\subsection{Feed expansion}

Changes in feed volume were monitored using heated feed pellets [25,32,33]. Pellets $\sim 13 \mathrm{~mm}$ in diameter and $\sim 6.5 \mathrm{~mm}$ high were prepared from $1.5 \mathrm{~g}$ dry feed and pressed at $\sim 7$ MPa. For each test, a pellet was heated at $5 \mathrm{~K} \mathrm{~min}^{-1}$ on an alumina plate in a windowed furnace, through which pictures were taken at different temperatures. Pellet profile areas were evaluated using Adobe Photoshop CS3 Extended. The platinum wire (10-mm in length) next to the pellet was used as a scale gauge, which allowed the program to calculate the cross-section areas of the pellets [32]. The measured areas were then normalized to the profile area of as-prepared cylindrical pellet (the standard deviation was $\sim 0.035$ [33]).

Fig. 9 shows the relative (i.e., normalized) profile area of pellets versus temperature. The $\mathrm{HLW}$ feed profile area remained nearly constant until it shrank at $\sim 700^{\circ} \mathrm{C}$, reaching a minimum at $\sim 800^{\circ} \mathrm{C}$, and then began to expand, creating foam that began to collapse at $\sim 930^{\circ} \mathrm{C}$. The profile area change of LAW feeds was more dramatic; the feeds started to expand earlier, AZ102 at $\sim 680^{\circ} \mathrm{C}$ and $\mathrm{AN}-102$ at $\sim 650^{\circ} \mathrm{C}$, rapidly creating ample foaming that culminated at $725^{\circ} \mathrm{C}$ and $775^{\circ} \mathrm{C}$ for $\mathrm{AN}-102$ and $\mathrm{AZ}-102$ feeds, respectively.

\section{Discussion}

Hanford wastes contain various amounts of nitrates, nitrites, carbonates, sulfates, and chromates. These salts are miscible when molten, forming a single liquid phase, the primary melt, in which Tc is dissolved in the form of pertechnetate (or Re as perrhenate in nonradioactive simulants). As temperature increases, carbonates, nitrates, and nitrites react with the solid feed components, releasing gases (Table 4), while the cations (usually alkalis) enter the glass-forming phase [29,34-36]. As a result, the salt-phase composition changes, turning from a mixture 
dominated by nitrate, nitrite, and carbonate to a mixture of sulfate, chromate, halides, and pertechnetate/perrhenate. Chromate provides yellow color to the sulfate phase. Chlorides and perrhenates were detected in the sulfate phase by Jin et al. [25].

The development of glass-forming phase starts with small pockets of borate glass that grow by absorbing metallic oxides from decomposing salts and reactive amorphous gels. The growing fraction of glass-forming phase causes the internal surface area of the feed to shrink, while leaving the porosity open for the escaping gas. When solid silica begins to dissolve, the fraction of glass-forming melt reaches a critical value at which the melt connects until it becomes continuous as can be seen in a scanning electron microscopy image in Ref. [37].

Then the internal surface area, on which the residual salt phase spreads, is reduced to bubbles, forcing the salt phase into isolated inclusions. The presence of sulfate in gas bubbles has been demonstrated in both commercial [38] and waste [39,40] glass melts. The buoyancy of bubbles can explain the observation that high-density perrhenates segregated on the top of borosilicate melt in sealed capsules in which a mixture of crushed glass with Re source was heated [26].

After the porosity closure, the reacting feed consists of continuous, yet inhomogeneous melt in which dissolving silica particles are suspended together with gas bubbles containing trapped residues of salt melt [41]. If the glass melt connects before all nitrates, nitrites and carbonates are fully decomposed, gas bubbles grow rapidly and turn the melt to foam. However, if nearly all nitrates, nitrites and carbonates are decomposed before the glass melt connects, bubbles still grow as additional gas is released from the glass-forming phase when the gas solubility decreases and the redox equilibria shift with increasing temperature, but only mild foaming occurs. 
As Fig. 9 demonstrates, HLW and LAW feeds are substantially different in their kinetics of gas release. In the high-alumina $\mathrm{HLW}$ feed, almost all $\mathrm{NO}_{\mathrm{x}}$ and $\mathrm{CO}_{2}$ evolve before $650^{\circ} \mathrm{C}$ and escape through open pores without producing foam [29]. The glass-forming melt connects at $\sim 800^{\circ} \mathrm{C}$. The gas that evolves above this temperature causes a relatively mild increase in volume and is released starting at $\sim 930^{\circ} \mathrm{C}$. In AZ-102 and AN-102 LAW feeds, the melt connects at $650-680^{\circ} \mathrm{C}$ whereas nitrates and nitrites continue to decompose until $750^{\circ} \mathrm{C}$ [24,25]. This early closure of foam and the protracted evolution of residual gas after the glass-forming melt was connected led to ample foaming.

Expanding foam begins to collapse internally [42] into larger foam cells and cavities that open to the atmosphere, releasing the salt phase on the top surface of the glass melt. While in bubbles and also on the melt surface, salt components continue to dissolve into the glass-forming melt, which is still inhomogeneous and contains dissolving silicate minerals (quartz particles in the case of the HLW feed [41]) and minor crystalline phases that continue to grow or dissolve. On the top surface of the melt, the salt begins to evaporate while still dissolving, releasing components according to their volatility governed by Henry’s law.

The differences in foaming behavior could probably explain why Re began to volatilize from $\mathrm{LAW}$ feeds at $\sim 600^{\circ} \mathrm{C}, \sim 200^{\circ} \mathrm{C}$ below the temperature at which pure $\mathrm{KReO}_{4}$ began to evaporate, and why Re did not volatilize from the $\mathrm{HLW}$ feed until $\sim 1000^{\circ} \mathrm{C}, \sim 200^{\circ} \mathrm{C}$ above the temperature at which pure $\mathrm{KReO}_{4}$ began to appreciably evaporate (Table 5), even though the $\mathrm{Re}$ addition was more than one thousand times higher in the HLW feed than in the LAW feeds. As mentioned above, ample foam provides a large internal surface area for the salt melt to spread on foam cells and then be released on the top surface of the melt when the foam is collapsing. Even 
before the onset of foaming, the vigorous reaction of nitrate-nitrite-carbonate melt in the LAW feeds exposes the perrhenate to a large constantly renewed boiling-like surface.

In the HLW feed, unlike in LAW feeds, almost all $\mathrm{NO}_{\mathrm{x}}$ and $\mathrm{CO}_{2}$ evolved and thus nearly all the salt became a mixture of sulfate and pertechnetate/perrhenate before the glass-forming melt became connected. As a result, virtually all perrhenate remained dissolved in sulfate, in which it was effectively protected against vaporization. The sulfate-perrhenate salt remained in bubbles until the bubbles began to collapse, releasing the salt melt on the glass surface, where it was exposed to evaporation, which was detected above $1000^{\circ} \mathrm{C}$ for all dissolved volatiles, including Re, Cs, and S (Fig. 2). Re evaporated somewhat faster than S and Cs (Fig. 3). An experiment with the HLW feed containing only 0.01 mass\% Re (the solid point in Fig. 2a) showed that the fraction of Re added had little effect on the extent of Re volatilization when the feed subjected to identical treatment.

Although some assertions of this discussion remain hypothetical until confirmed by future studies, the fact that $\operatorname{Re}$ (and most probably Tc) can be retained at a high fraction to a high temperature in the HLW suggests that the HLW glass is possibly a suitable medium for Tc immobilization.

We conclude this discussion with the following remarks. First, volatilization of dissolved Re from glass melt surface is conceivable, provided that Marangoni convection [43] driven by surface forces associated with decreased concentrations of surface active components causes a rapid surface renewal [44]. Unless volatilization of light components dominates the melt density, surface renewal by buoyancy driven convection is unlikely because melt density drops when $\operatorname{Re}$ content decreases. 
Second, not all undissolved Re would leave the melt in bubbles; excess Re can be retained in glass in the form of micro- or nano- inclusions, possibly as a mixture of $\mathrm{MReO}_{4}$ with sulfate ( $\mathrm{M}$ is alkali metal). This was probably the case with the high Re fraction retained in HLW glass at $1200^{\circ} \mathrm{C}(\sim 0.6$ mass \%), which most likely exceeds Re solubility (it is unlikely that $\operatorname{Re}$ solubility in the high-alumina HLW is higher than the 0.3 mass $\%$ measured in the LAW glass [20]).

Third, the extrapolation of the $\mathrm{Re}_{2} \mathrm{O}_{7}$ fraction retained to long bubbling time (Fig. 7a) indicates that a portion of Re resists removal from iron phosphate glass (similar to Cs, though to a much lesser extent), while $S$ could possibly be removed completely.

Finally, other factors, which were not discussed above, yet should not be ignored, may affect Re volatilization behavior. Substantial differences in glass-forming and glass-modifying feed materials used for HLW and LAW borosilicate glasses and in HLW and LAW waste compositions result in differences in the feed-to-glass conversion process. For example, the high surface area of amorphous aluminum oxide from the decomposition of aluminum hydroxide, a major component of the HLW glass (Table 1) [36,45], provides a large internal surface that may selectively immobilize the salt melt, whereas LAW feeds consist mainly of water-free minerals (Table 3) that do not provide a comparable active surface area.

\section{Conclusion}

The kinetics of Re volatilization from melter feeds for waste glasses of various types, all containing sulfate as a minor component, reveals a variety of Re volatilization behaviors. The low-temperature release observed in LAW melter feeds can be attributed to the large content of oxyionic salts and vigorous foaming. High-temperature release that occurred from both the HLW 
and LAW melts can be attributed to release of sulfate-halide-perrhenate/pertechnetate melt to the glass surface from collapsing bubbles. If confirmed by further investigation, the HLW glass with less foaming and salts is a potentially promising medium for Tc immobilization.

\section{Acknowledgements}

This work was supported by the Department of Energy's Waste Treatment and Immobilization Plant Federal Project Office. The authors are grateful to Drs. Dong-Sang Kim and Tongan Jin for their data on Re in LAW borosilicate glasses and insightful discussion, Steven Luksic for his data on low addition of Re (0.01 mass\%) in HLW feed, and Zach Hilliard for his help on feed expansion. Pacific Northwest National Laboratory is operated by Battelle Memorial Institute for the U.S. Department of Energy under contract DE-AC05-76RL01830.

\section{References}

[1] K.V. Kotegov, O.N. Pavlov, V.P. Shvedov, Adv. Inorg. Chem., 11 (1968), pp. 1-90.

[2] J.P. Icenhower, N.P. Qafoku, J.M. Zachara, W.J. Martin, Am. J. Sci., 310 (2010), pp. 721752.

[3] Fluor Hanford, Inc., Hanford Integrated Groundwater and Vadose Zone Management Plan, DOE/RL-2007-20, Prepared for the U.S. Department of Energy Assistant Secretary for Environmental Management under Contract DE-AC06-96RL13200, Richland, WA, 2007.

[4] J.G. Darab, P.A. Smith, Chem. Mater., 8 (1996), pp. 1004-1021.

[5] R.J. Serne, B.M. Rapko, Technetium Inventory, Distribution and Speciation in Hanford Tanks, PNNL-23319, Pacific Northwest National Laboratory, Richland, WA, 2014. 
[6] D.E. Day, R.K. Brow, C.S. Ray, C.W. Kim, Formulation of Iron Phosphate Glasses with Simulated Hanford LAW for Joule Heated and Cold Crucible Induction Melters, Final report for Battelle Memorial Institute Pacific Northwest Division, Contract No. 120936, submitted to Pacific Northwest National Laboratory under DOE, contract DE-AC05-76RL01830, 2011.

[7] K. Xu, P. Hrma, W. Um, J. Heo, J. Nucl. Mater., 441 (2013), pp. 262-266.

[8] W.W. Luckens, J.J. Bucher, D.K. Shuh, N.M. Edelstein, Environ. Sci. Technol., 39 (2005), pp. 8064-8070.

[9] J.H. Westsik Jr., W. Um, N.P. Qafoku, G.B. Josephson, R.J. Serne, Capture and Immobilization of Technetium from Liquid Radioactive Waste Streams into a Stable Goethite Form-11351, WM2011 Conference, February 27 - March 3, 2011, Phoenix, AZ.

[10] D. Singh, V.R. Mandalika, S.J. Parulekar, A.S. Wagh, J. Nucl. Mater., 348 (2006), pp. 272282.

[11] E.R. Vance, K.P. Hart, R.A. Day, M.L. Carter, M. Hambley, M.G. Blackford, B.D. Begg, Scientific Basis for Nuclear Waste Management XX, Materials Research Society Symposium Proceedings, vol. 465, 1997, pp. 341-348.

[12] W. Um, H.S. Chang, J.P. Icenhower, W.W. Lukens, R.J. Serne, N.P. Qafoku, J.H. Westsik Jr., E.C. Buck, S.C. Smith, Environ. Sci. Technol., 45 (2011), pp. 4904-4913.

[13] W. Um, H.S. Chang, J.P. Icenhower, W.W. Lukens, R.J. Serne, N.P. Qafoku, R.K. Kukkadapu, J.H. Westsik Jr., J. Nucl. Mater., 429 (2012), pp 201-209.

[14] J.H. Westsik Jr., K.J. Cantrell, R.J. Serne, N.P. Qafoku, Technetium Immobilization Forms Literature Survey, PNNL-23329, Pacific Northwest National Laboratory, Richland, WA, 2014. [15] H. Lammertz, E. Merz, St. Halaszovich, Technetium Volatilization during HLLW Vitrification, Materials Research Society Symposium Proceedings, vol. 44, 1985, pp. 823-829. 
[16] K.S. Matlack, I.S. Muller, I. Joseph, I.L. Pegg, Improving Technetium Retention in Hanford LAW Glass - Phase 1, VSL-10R1920-1, Vitreous State Laboratory, The Catholic University of America, Washington, DC, 2010.

[17] K.S. Matlack, I.S. Muller, R.A. Callow, N. D’Angelo, T. Bardacki, I. Joseph, I.L. Pegg, Improving Technetium Retention in Hanford LAW Glass - Phase 2, VSL-11R2260-1, Vitreous State Laboratory, The Catholic University of America, Washington, DC, 2011.

[18] I.L. Pegg, J. Radioanal. Nucl. Chem., (2015), DOI 10.1007/s10967-014-3900-9.

[19] C.Z. Soderquist, M.J. Schweiger, D.S. Kim, W.W. Lukens, J.S. McCloy, J. Nucl. Mater., 449 (2014), pp. 173-180.

[20] J.S. McCloy, B.J. Riley, A. Goel, M. Liezer, M.J. Schweiger, C.P. Rodriguez, P. Hrma, D.S. Kim, Environ. Sci. Technol., 46 (2012), pp. 12616-12622.

[21] O. Muller, W.B. White, R. Roy, J. Inorg. Nucl. Chem., 26 (1964), pp. 2075-2086.

[22] J.O. Dickson, The Role of Secondary Aluminosilicate Minerals in Technetium-99

Immobilization in Radioactive Waste, Ph. D Thesis, Washington State University, Pullman, WA, 2014.

[23] J.O. Dickson, J.B. Harsh, M. Flury, W.W. Lukens, E.M. Pierce, Environ. Sci. Technol., 48 (2014), pp. 12851-12857.

[24] T. Jin, D.S. Kim, M.J. Schweiger, Effect of Sulfate on Rhenium Partitioning during Melting of Low-Activity Waste Glass Feeds-14116, Waste Management (WM) 2014 Conference, March 2-6, 2014, Phoenix, AZ.

[25] T. Jin, D.S. Kim, R.M. Covert, A. Tucker, M.J. Schweiger, A.A. Kruger, Reactions during Melting of Low-Activity Waste Glass Feeds and Their Effects on the Retention of Rhenium as a Surrogate for Technetium-99, paper under review. 
[26] B.J. Riley, J.S. McCloy, A. Goel, M. Liezer, M.J. Schweiger, J. Liu, C.P. Rodriguez, D.S. Kim, J. Am. Ceram. Soc., 96 (2013), pp. 1150-1157.

[27] M.J. Schweiger, P. Hrma, C.J. Humrickhouse, J. Marcial, B.J. Riley, N.E. TeGrotenhuis, J. Non-Cryst. Solids, 356 (2010), pp. 1359-1367.

[28] C.L. Schutte, G.M. Whitesides, Chem. Mater., 268 (1991), pp. 267-271.

[29] C. Rodriguez, J. Chun, M.J. Schweiger, A.A. Kruger, P. Hrma, Thermochim Acta., 592 (2014), pp. 56-92.

[30] D.E. Day, C.S. Ray, C.W. Kim, Iron Phosphate Glasses: An Alternative for Vitrifying Certain Nuclear Wastes, Final report for DE-FG07-96ER45618, Project No. 73976, submitted to the Environmental Management Science Program, US-DOE, 2004.

[31] D.S. Kim, M.J. Schweiger, W.C. Buchmiller, J.D. Vienna, D.E. Day, D. Zhu, C.W. Kim, T.E. Day, T. Neidt, D.K. Peeler, T.B. Edwards, I.A. Reamer, R.J. Workman, Iron Phosphate Glass as An Alternative Waste-Form for Hanford LAW, PNNL-14251, Pacific Northwest National Laboratory, Richland, WA, 2003.

[32] D.A. Pierce, P. Hrma, J. Marcial, B.J. Riley, M.J. Schweiger, Int. J. Appl. Glass Sci., 3 (2012), pp. 59-68.

[33] S.H. Henager, P. Hrma, K.J. Swearingen, M.J. Schweiger, J. Marcial, N.E. TeGrotenhuis, J. Non-Cryst. Solids, 357 (2011), pp. 829-835.

[34] R. Pokorny, D.A. Pierce, P. Hrma, Thermochim Acta., 541 (2012), pp. 8-14.

[35] J. Chun, D.A. Pierce, R. Pokorny, P. Hrma, Thermochim Acta., 559 (2013), pp. 32-39.

[36] K. Xu, P. Hrma, J. Rice, M.J. Schweiger, B.J. Riley, J.V. Crum, Melter Feed Reactions at $T$ $\leq 600^{\circ} \mathrm{C}$ for Nuclear Waste Vitrification, paper under review.

[37] P. Hrma, Ceram. Trans., 250 (2014), pp. 137-145. 
[38] R.G.C. Beerkens, J. Am. Ceram. Soc., 86 (2003), pp. 1893-1199.

[39] P. Hrma, J.D. Vienna, W.C. Buchmiller, J.S. Ricklefs, Ceram. Trans., 155 (2004), pp. 93-

100.

[40] P. Hrma, J.D. Vienna, J.S. Ricklefs, Mat. Res. Soc. Proc., 757 (2003), pp. 147-152.

[41] J. Marcial, J. Chun, P. Hrma, M.J. Schweiger, Environ. Sci. Technol., 48 (2014), pp. 1217312180.

[42] P. Hrma, J. Non-Cryst. Solids, 355 (2009), pp. 257-263.

[43] M. K. Smith, S. H. Davis, J. Fluid Mech., 132 (1983), pp 119-114.

[44] P. Hrma, Glass Technol., 23 (1982), pp. 151-155.

[45] K. Xu, P. Hrma, M.J. Schweiger, Specific Surface Area Change of Melter Feed for Vitrification of Hanford High-Alumina High-Level Waste, unpublished results. 


\section{Tables}

Table 1. High-alumina HLW batch and nominal glass composition.

\begin{tabular}{|c|c|c|c|}
\hline \multicolumn{2}{|c|}{ Batch sheet for $\sim 1000 \mathrm{~g}$ of HLW glass $(\mathrm{g})$} & \multicolumn{2}{|c|}{ Nominal glass composition (mass\%) } \\
\hline $\mathrm{Al}(\mathrm{OH})_{3}$ & 357.76 & $\mathrm{SiO}_{2}$ & 29.57 \\
\hline $\mathrm{H}_{3} \mathrm{BO}_{3}$ & 262.68 & $\mathrm{Al}_{2} \mathrm{O}_{3}$ & 23.28 \\
\hline $\mathrm{CaO}$ & 59.16 & $\mathrm{~B}_{2} \mathrm{O}_{3}$ & 14.72 \\
\hline $\mathrm{Fe}(\mathrm{OH})_{3}$ & 71.88 & $\mathrm{CaO}$ & 5.89 \\
\hline $\mathrm{Li}_{2} \mathrm{CO}_{3}$ & 85.96 & $\mathrm{Fe}_{2} \mathrm{O}_{3}$ & 5.73 \\
\hline $\mathrm{Mg}(\mathrm{OH})_{2}$ & 1.64 & $\mathrm{Li}_{2} \mathrm{O}$ & 3.46 \\
\hline $\mathrm{NaOH}$ & 90.96 & $\mathrm{Na}_{2} \mathrm{O}$ & 9.72 \\
\hline $\mathrm{SiO}_{2}$ & 296.96 & $\mathrm{~K}_{2} \mathrm{O}$ & 0.25 \\
\hline $\mathrm{Zn}\left(\mathrm{NO}_{3}\right)_{2} \cdot 4 \mathrm{H}_{2} \mathrm{O}$ & 2.60 & $\mathrm{MgO}$ & 0.11 \\
\hline $\mathrm{Zr}(\mathrm{OH})_{4} \cdot 0.65 \mathrm{H}_{2} \mathrm{O}$ & 5.36 & $\mathrm{ZrO}_{2}$ & 0.38 \\
\hline $\mathrm{Na}_{2} \mathrm{SO}_{4}$ & 3.44 & $\mathrm{ZnO}$ & 0.08 \\
\hline $\mathrm{Bi}(\mathrm{OH})_{3}$ & 12.48 & $\mathrm{Bi}_{2} \mathrm{O}_{3}$ & 1.11 \\
\hline $\mathrm{Na}_{2} \mathrm{CrO}_{4}$ & 10.84 & $\mathrm{NiO}$ & 0.39 \\
\hline $\mathrm{NiCO}_{3}$ & 6.20 & $\mathrm{PbO}$ & 0.40 \\
\hline $\mathrm{Pb}\left(\mathrm{NO}_{3}\right)_{2}$ & 5.92 & $\mathrm{Cr}_{2} \mathrm{O}_{3}$ & 0.51 \\
\hline $\mathrm{Fe}\left(\mathrm{H}_{2} \mathrm{PO}_{2}\right)_{3}$ & 12.08 & $\mathrm{P}_{2} \mathrm{O}_{5}$ & 1.02 \\
\hline $\mathrm{NaF}$ & 14.40 & $\mathrm{SO}_{3}$ & 0.19 \\
\hline $\mathrm{NaNO}_{3}$ & 12.32 & $\mathrm{Re}_{2} \mathrm{O}_{7}$ & 1.26 \\
\hline $\mathrm{NaNO}_{2}$ & 3.36 & $\mathrm{Cs}_{2} \mathrm{O}$ & 0.31 \\
\hline $\mathrm{Na}_{2} \mathrm{C}_{2} \mathrm{O}_{4}$ & 1.24 & $\mathrm{~F}$ & 0.65 \\
\hline $\mathrm{NaI}$ & 11.48 & I & 0.97 \\
\hline $\mathrm{KReO}_{4}$ & 15.12 & & \\
\hline $\mathrm{Cs}_{2} \mathrm{CO}_{3}$ & 3.56 & & \\
\hline Total & 1347.4 & & 100 \\
\hline
\end{tabular}


Table 2a. Compositions of AZ-102 and AN-102 LAW feed batches [16,17].

\begin{tabular}{|c|c|c|}
\hline \multicolumn{3}{|c|}{ Batch sheet for $\sim 1000 \mathrm{~g}$ of LAW glass $(\mathrm{g}$ ) } \\
\hline Waste & AZ-102 & AN-102 \\
\hline $\mathrm{Al}\left(\mathrm{NO}_{3}\right)_{3} \cdot 9 \mathrm{H}_{2} \mathrm{O}$ & 1.22 & 76.81 \\
\hline $\mathrm{H}_{3} \mathrm{BO}_{3}$ & 0 & 0.09 \\
\hline $\mathrm{Ca}\left(\mathrm{NO}_{3}\right)_{2} \cdot 4 \mathrm{H}_{2} \mathrm{O}$ & 0 & 1.28 \\
\hline $\mathrm{Na}_{2} \mathrm{CrO}_{4} \cdot 4 \mathrm{H}_{2} \mathrm{O}$ & 2.41 & 2.41 \\
\hline $\mathrm{KOH}$ & 6.44 & 6.44 \\
\hline $\mathrm{NaOH}$ & 2.21 & 46.18 \\
\hline $\mathrm{NiO}$ & 0.08 & 0.08 \\
\hline $\mathrm{PbO}$ & 0.08 & 0.08 \\
\hline $\mathrm{SiO}_{2}$ & 0.26 & 0.09 \\
\hline $\mathrm{NaCl}$ & 3.25 & 3.25 \\
\hline $\mathrm{NaF}$ & 1.72 & 1.72 \\
\hline $\mathrm{Na}_{3} \mathrm{PO}_{4} \cdot 12 \mathrm{H}_{2} \mathrm{O}$ & 6.56 & 6.60 \\
\hline $\mathrm{Na}_{2} \mathrm{SO}_{4}$ & 14.20 & 10.54 \\
\hline $\mathrm{NaNO}_{2}$ & 24.81 & 56.57 \\
\hline $\mathrm{NaNO}_{3}$ & 6.76 & 82.64 \\
\hline $\mathrm{Na}_{2} \mathrm{CO}_{3}$ & 28.62 & 42.97 \\
\hline Sodium Formate $\left(\mathrm{NaHCO}_{2}\right)$ & 0 & 21.74 \\
\hline Sodium Oxalate $\left(\mathrm{Na}_{2} \mathrm{C}_{2} \mathrm{O}_{4}\right)$ & 0 & 1.26 \\
\hline Glycolic Acid $\left(\mathrm{C}_{2} \mathrm{H}_{4} \mathrm{O}_{3}\right)$ & 0 & 26.72 \\
\hline Citric Acid $\left(\mathrm{C}_{6} \mathrm{H}_{8} \mathrm{O}_{7}\right)$ & 0 & 7.84 \\
\hline Oxalic Acid $\left(\left(\mathrm{C}_{2}\right) \cdot 2 \mathrm{H}_{2} \mathrm{O}\right)$ & 2.24 & 0 \\
\hline $\mathrm{Re}_{2} \mathrm{O}_{7}$ & 0.01 & 0.01 \\
\hline \multicolumn{3}{|l|}{ Additives } \\
\hline Kyanite $\left(\mathrm{Al}_{2} \mathrm{SiO}_{5}\right)$ & 104.60 & 86.21 \\
\hline Borax $\left(\mathrm{H}_{3} \mathrm{BO}_{3}\right)$ & 176.75 & 175.13 \\
\hline Wollanstonite $\left(\mathrm{CaSiO}_{3}\right)$ & 150.50 & 135.78 \\
\hline Hematite $\left(\mathrm{Fe}_{2} \mathrm{O}_{3}\right)$ & 50.10 & 51.92 \\
\hline $\mathrm{Li}_{2} \mathrm{CO}_{3}$ & 105.46 & 78.47 \\
\hline Olivine $\left(\mathrm{Mg}_{2} \mathrm{SiO}_{4}\right)$ & 61.24 & 31.04 \\
\hline $\mathrm{Na}_{2} \mathrm{CO}_{3}$ & 23.77 & 0 \\
\hline $\mathrm{SiO}_{2}$ & 329.98 & 316.35 \\
\hline Rutile $\left(\mathrm{TiO}_{2}\right)$ & 13.15 & 13.29 \\
\hline Zincite ( $\mathrm{ZnO})$ & 34.80 & 34.60 \\
\hline Zircon $\left(\mathrm{ZrSiO}_{4}\right)$ & 44.83 & 44.38 \\
\hline Total & 1196.05 & 1362.49 \\
\hline
\end{tabular}


Table 2b. Nominal glass compositions (mass\%) of AZ-102 and AN-102 LAW glasses [16,17].

\begin{tabular}{lrr}
\hline Oxide Component & AZ-102 & AN-102 \\
\hline $\mathrm{SiO}_{2}$ & 48.92 & 44.75 \\
$\mathrm{Al}_{2} \mathrm{O}_{3}$ & 6.07 & 6.02 \\
$\mathrm{~B}_{2} \mathrm{O}_{3}$ & 9.95 & 9.87 \\
$\mathrm{CaO}$ & 6.96 & 6.31 \\
$\mathrm{Fe}_{2} \mathrm{O}_{3}$ & 5.48 & 5.43 \\
$\mathrm{Li}_{2} \mathrm{O}$ & 4.26 & 3.17 \\
$\mathrm{Na}_{2} \mathrm{O}$ & 5.72 & 13.53 \\
$\mathrm{~K}_{2} \mathrm{O}$ & 0.54 & 0.54 \\
$\mathrm{MgO}$ & 2.94 & 1.49 \\
$\mathrm{ZrO}$ & 2.99 & 2.96 \\
$\mathrm{ZnO}$ & 3.48 & 3.46 \\
$\mathrm{NiO}$ & 0.01 & 0.01 \\
$\mathrm{PbO}_{\mathrm{Cr}}$ & 0.01 & 0.01 \\
$\mathrm{TiO}_{2}$ & 0.08 & 0.08 \\
$\mathrm{P}_{2} \mathrm{O}_{5}$ & 1.39 & 1.38 \\
$\mathrm{SO}_{3}$ & 0.12 & 0.12 \\
$\mathrm{Cl}$ & 0.80 & 0.59 \\
$\mathrm{~F}$ & 0.20 & 0.20 \\
$\mathrm{Re}($ ppm $)$ & 0.08 & 0.08 \\
& 8.1 & 8.1 \\
\hline
\end{tabular}


Table 3. Nominal iron phosphate glass composition (mass\%) of AZ-102 LAW melter feed, raw materials used in batch [6].

\begin{tabular}{|c|c|c|}
\hline Component & Mass Fraction & Raw Materials \\
\hline $\mathrm{Al}_{2} \mathrm{O}_{3}$ & 13.21 & $\mathrm{Al}\left(\mathrm{PO}_{3}\right)_{3}, \mathrm{AlPO}_{4}$ \\
\hline $\mathrm{B}_{2} \mathrm{O}_{3}$ & 0.03 & $\mathrm{H}_{3} \mathrm{BO}_{3}$ \\
\hline $\mathrm{Cl}$ & 0.04 & $\mathrm{NaCl}$ \\
\hline $\mathrm{Cr}_{2} \mathrm{O}_{3}$ & 2.70 & $\mathrm{Cr}_{2} \mathrm{O}_{3}$ \\
\hline $\mathrm{F}$ & 0.16 & $\mathrm{NaF}$ \\
\hline $\mathrm{K}_{2} \mathrm{O}$ & 0.78 & $\mathrm{KNO}_{3}$ \\
\hline $\mathrm{Na}_{2} \mathrm{O}$ & 20.03 & $\mathrm{NaNO}_{3}$ \\
\hline $\mathrm{P}_{2} \mathrm{O}_{5}$ & 38.06 & $\mathrm{Al}\left(\mathrm{PO}_{3}\right)_{3}, \mathrm{AlPO}_{4}$ \\
\hline $\mathrm{SiO}_{2}$ & 5.58 & $\mathrm{SiO}_{2}$ \\
\hline $\mathrm{Bi}_{2} \mathrm{O}_{3}$ & 1.77 & $\mathrm{Bi}(\mathrm{OH})_{3}$ \\
\hline $\mathrm{CaO}$ & 1.06 & $\mathrm{CaHPO}_{4}$ \\
\hline $\mathrm{Fe}_{2} \mathrm{O}_{3}$ & 7.10 & $\mathrm{Fe}_{2} \mathrm{O}_{3}$ \\
\hline $\mathrm{La}_{2} \mathrm{O}_{3}$ & 0.71 & $\mathrm{La}_{2} \mathrm{O}_{3}$ \\
\hline $\mathrm{ZnO}$ & 3.55 & $\mathrm{ZnO}$ \\
\hline $\mathrm{ZrO}_{2}$ & 0.71 & $\mathrm{ZrO}_{2}$ \\
\hline $\mathrm{Cs}_{2} \mathrm{O}$ & 0.13 & $\mathrm{CsNO}_{3}$ \\
\hline $\operatorname{Re}_{2} \mathrm{O}_{7}$ & 0.03 & $\mathrm{Re}_{2} \mathrm{O}_{7}$ \\
\hline $\mathrm{SO}_{3}$ & 4.37 & $\mathrm{Na}_{2} \mathrm{SO}_{4}$ \\
\hline Total & 100.00 & \\
\hline
\end{tabular}

Table 4. Contents of volatiles (in mass\% per glass) in high-alumina HLW, AZ-102, and AN-102 LAW feeds.

\begin{tabular}{lccccc}
\hline \multicolumn{1}{c}{ Sample } & $\mathrm{SO}_{3}$ & $\mathrm{NO}$ & $\mathrm{CO}_{2}{ }^{(\mathrm{a})}$ & $\mathrm{Re}$ & Mole ratio of S/N \\
\hline $\mathrm{HLW}$ & 0.19 & 0.75 & $5.42(5.48)$ & 0.97 & 0.10 \\
$\mathrm{AZ}-102$ & 0.80 & 1.35 & $8.46(8.61)$ & $8.1 \times 10^{-4}$ & 0.22 \\
$\mathrm{AN}-102$ & 0.59 & 7.25 & $7.95(12.12)$ & $8.1 \times 10^{-4}$ & 0.03 \\
\hline
\end{tabular}

(a) The values in parentheses show total $\mathrm{CO}_{2}$ including organic carbon. 
Table 5. Re volatilization onset temperature, $T_{O}$, and retention ratio, $R_{i T}$, at $1100^{\circ} \mathrm{C}$ in highalumina HLW, AZ-102, and AZ-102 feed samples heated at $5 \mathrm{~K} \mathrm{~min}^{-1}$. The sample depth, $h$, is also listed.

\begin{tabular}{lccc}
\hline \multicolumn{1}{c}{ Sample } & $T_{O}\left({ }^{\circ} \mathrm{C}\right)$ & $R_{i T}(\%)$ & $h(\mathrm{~mm})$ \\
\hline $\mathrm{HLW}$ & $\sim 1000$ & $\sim 83$ & $\sim 10$ \\
$\mathrm{AZ}-102$ & $\sim 600$ & $\sim 65$ & $\sim 12$ \\
$\mathrm{AN}-102$ & $\sim 600$ & $\sim 39$ & $\sim 12$ \\
$\mathrm{KReO}_{4}$ & $\sim 800$ & 0 & $\sim 1$ \\
\hline
\end{tabular}




\section{Figure Captions}

Fig. 1. Fraction of mass retained $\left(F_{T}\right)$ of high-alumina HLW melter feed as a function of test temperature. Dashed lines were added as guides to the eyes.

Fig. 2. Retention ratios of (a) Re, (b) Cs and (c) $\mathrm{S}$ in high-alumina HLW feed versus temperature. Solid square represents Re retention in HLW feed with target Re concentration of $100 \mathrm{ppm}$ at $1150^{\circ} \mathrm{C}$ during heating at $5 \mathrm{~K} \mathrm{~min}^{-1}$.

Fig. 3. Relative mass concentration ratios of Re to $S$ and Re to Cs in high-alumina HLW feed versus temperature.

Fig. 4. Retention ratios $\left(R_{\text {iTave }}\right)$ of other alkalis $(\mathrm{Na}, \mathrm{Li}$, and $\mathrm{K})$ in high-alumina $\mathrm{HLW}$ feed versus temperature.

Fig. 5. I retention ratio in high-alumina HLW feed versus temperature. Data were fitted with the exponential function $R_{I}=\exp \left(-\frac{T}{T_{0}}\right)$, where $T_{0}=225^{\circ} \mathrm{C}$.

Fig. 6. Re and S retention ratios in AZ-102 and AN-102 LAW melter feeds versus temperature. Dashed lines were added as guides to the eyes.

Fig. 7. Concentrations of (a) $\mathrm{Re}_{2} \mathrm{O}_{7}$, (b) $\mathrm{SO}_{3}$ and (c) $\mathrm{Cs}_{2} \mathrm{O}$ in LAW iron phosphate glass at $1050^{\circ} \mathrm{C}$ versus bubbling time. Data were fitted with exponential functions (dashed lines).

Fig. 8. Mass fraction of $\mathrm{KReO}_{4}$ (melting point: $550^{\circ} \mathrm{C}$ ) retained in the crucible versus temperature. Samples were heated at $5 \mathrm{~K} \mathrm{~min}^{-1}$. Dashed line was added as guide to the eyes. Fig. 9. Expansion of pellets made from high-alumina HLW, AZ-102 and AN-102 LAW [25] feeds versus temperature. Samples were heated at $5 \mathrm{~K} \mathrm{~min}^{-1}$. Lines were added as guides to the eyes. 


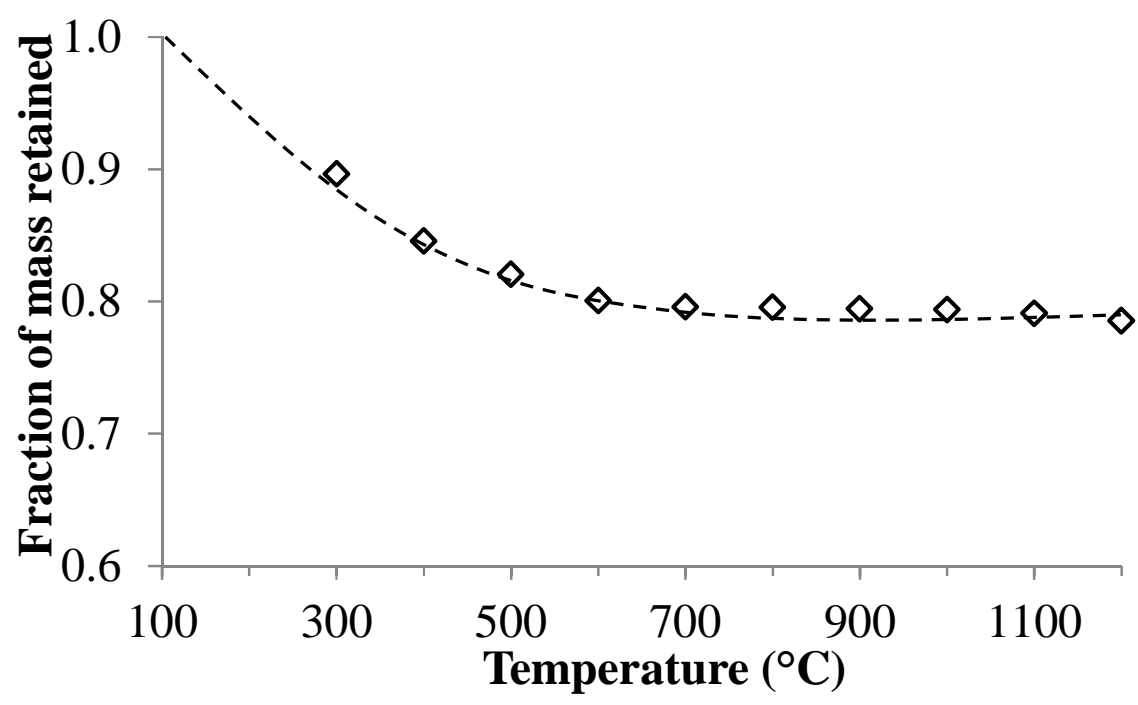

Fig. 1 

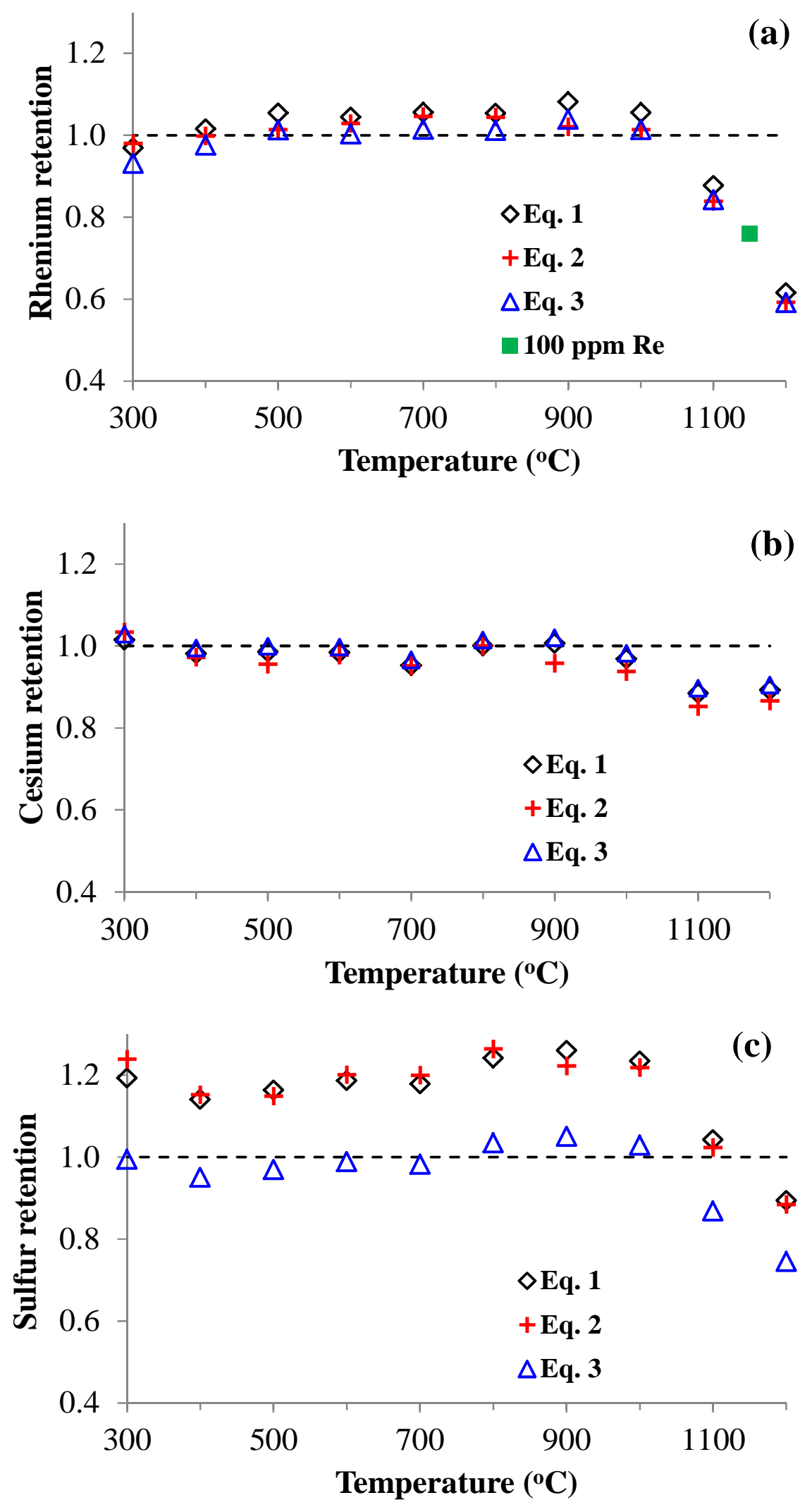

Fig. 2 


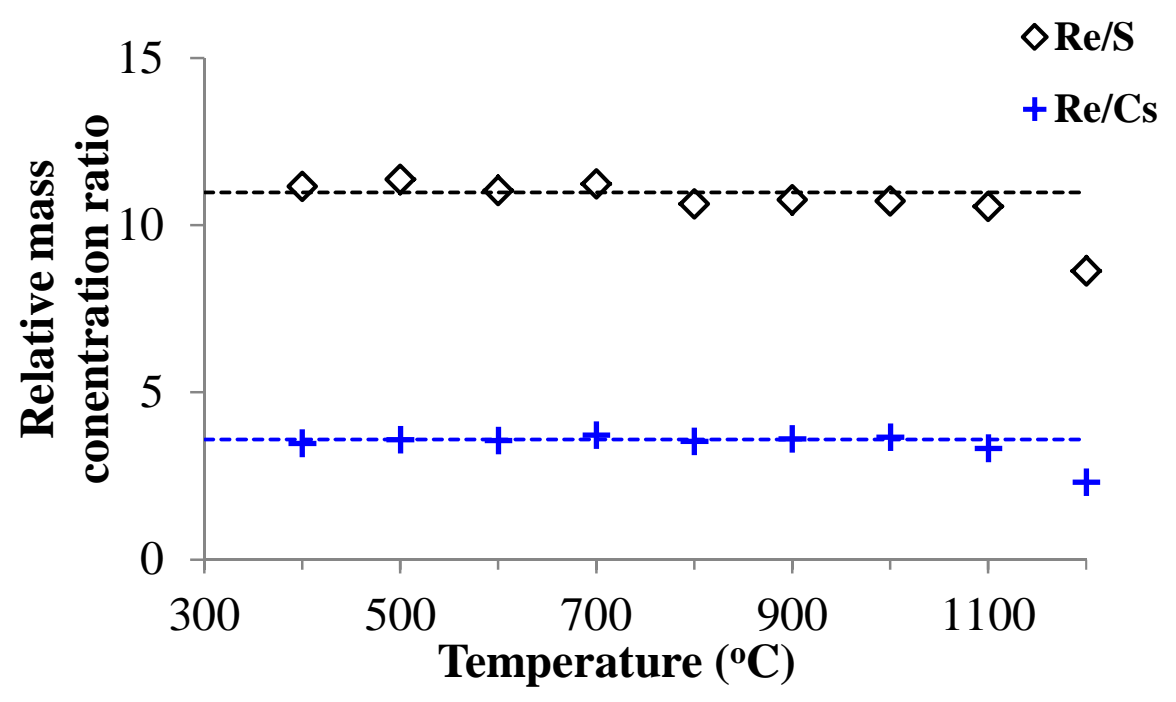

Fig. 3

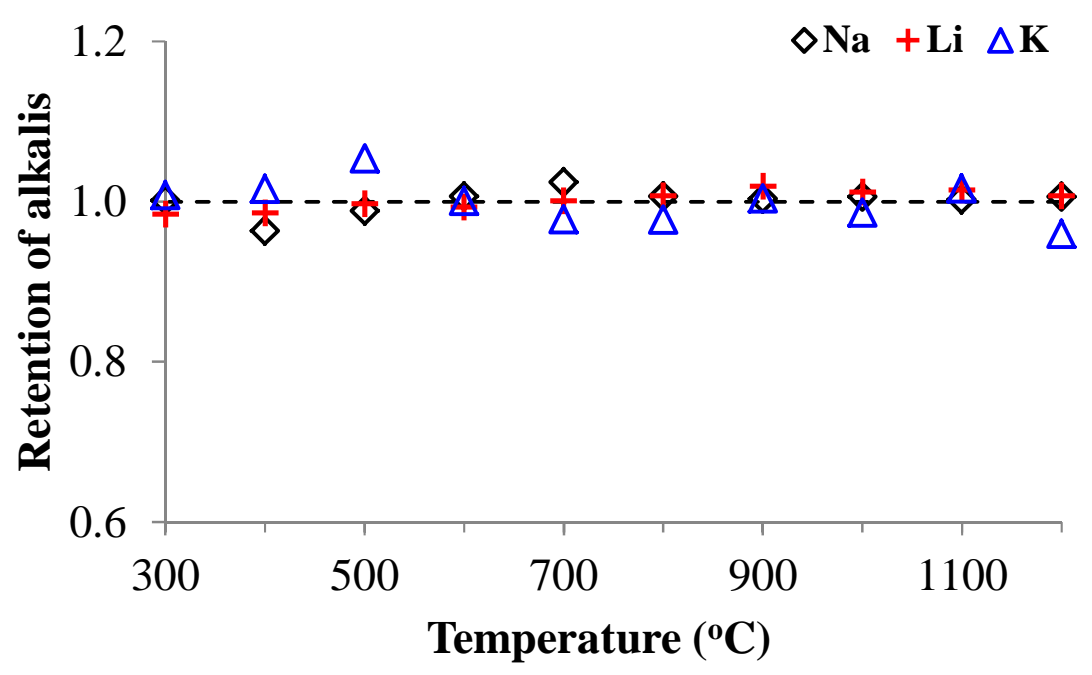

Fig. 4 


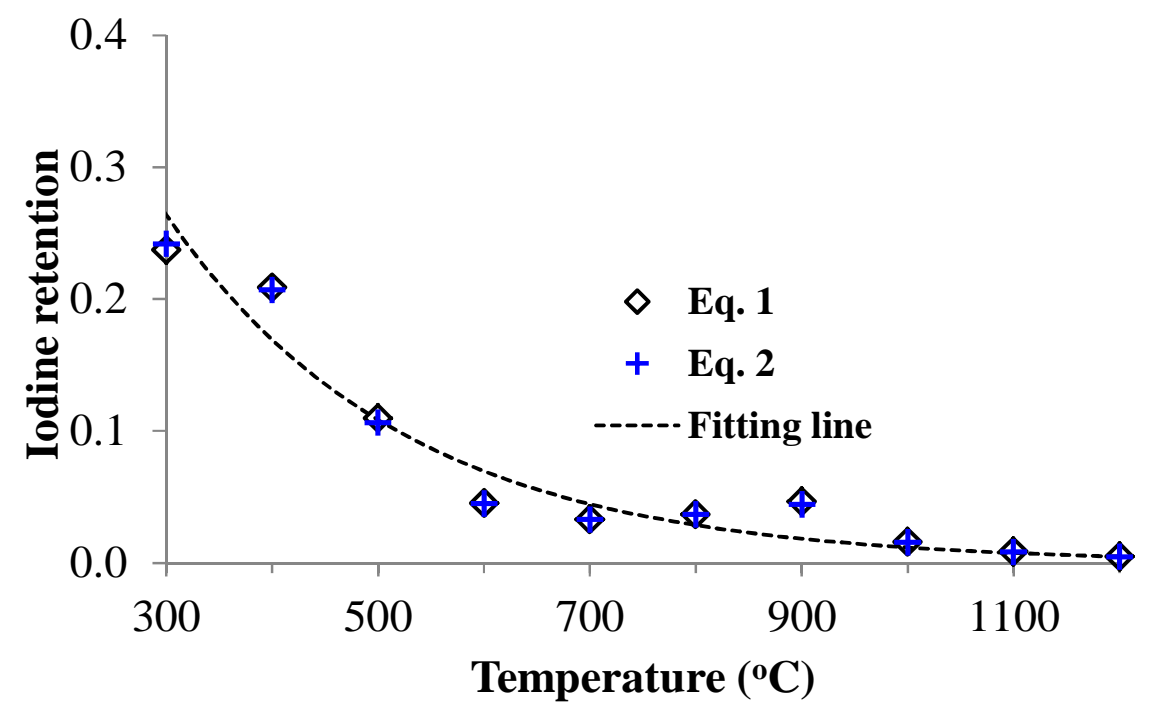

Fig. 5

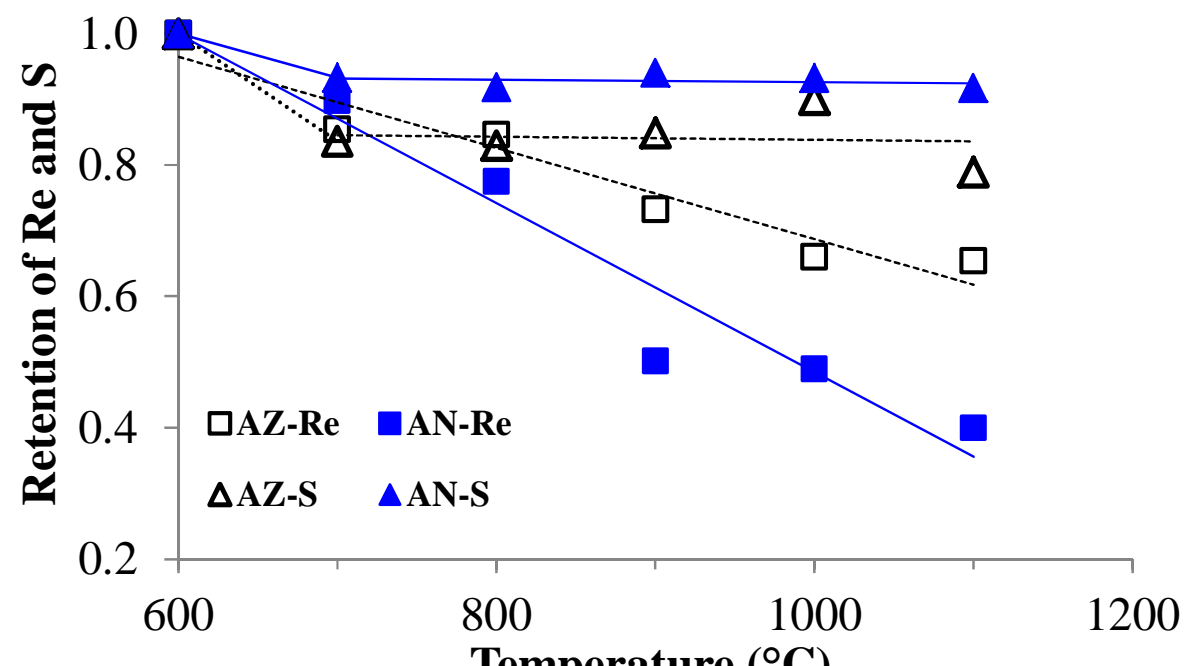

Fig. 6 
(a)

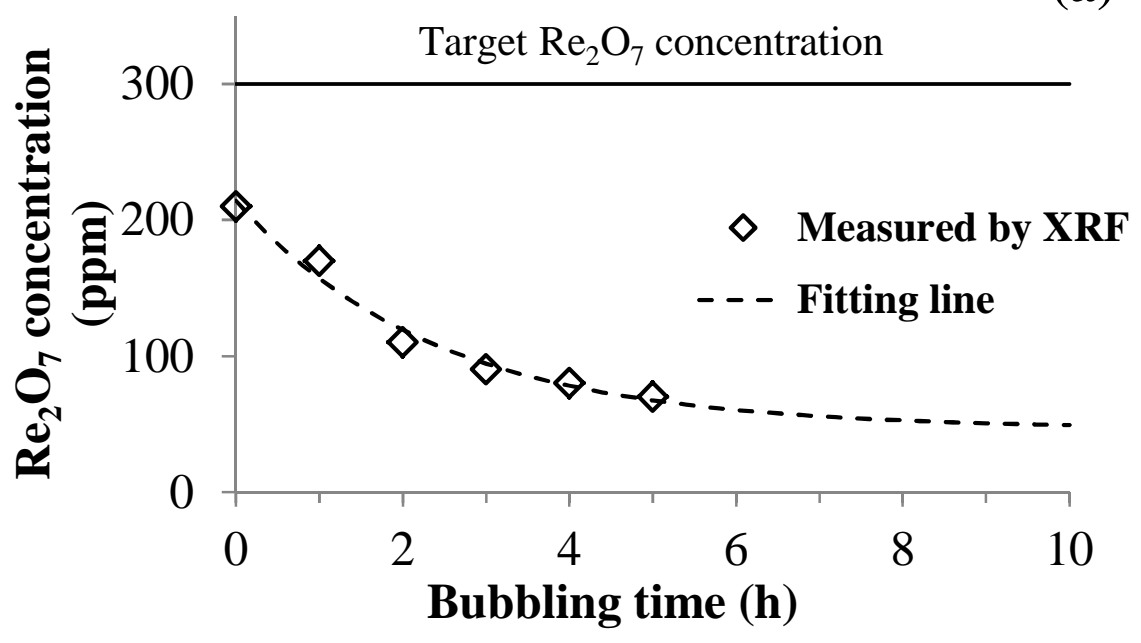

(b)

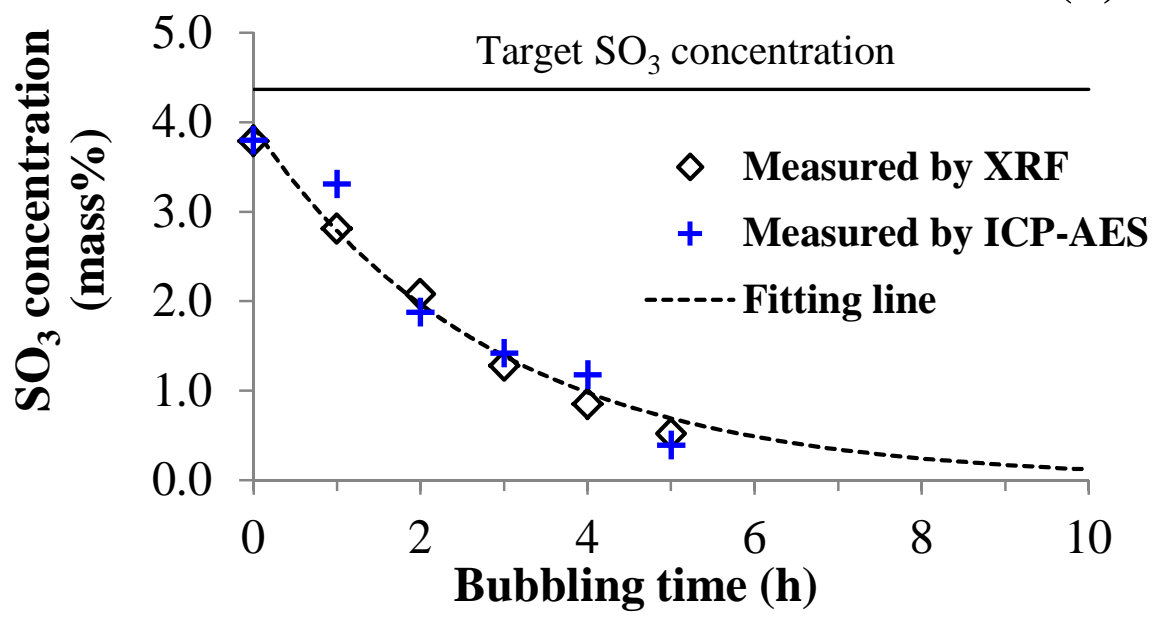

(c)

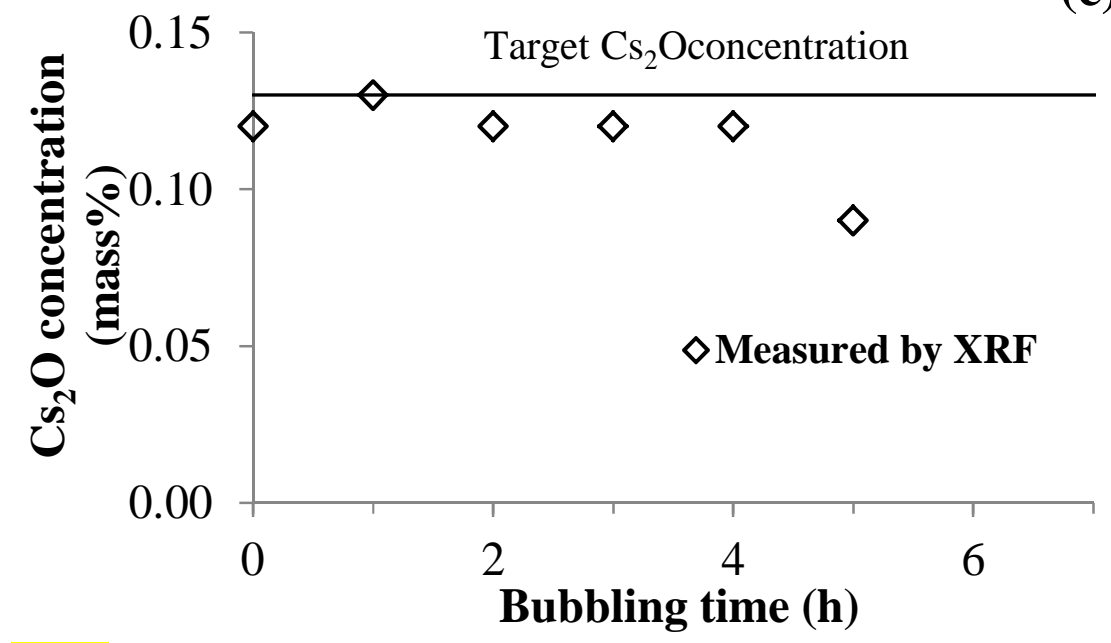

Fig. 7 


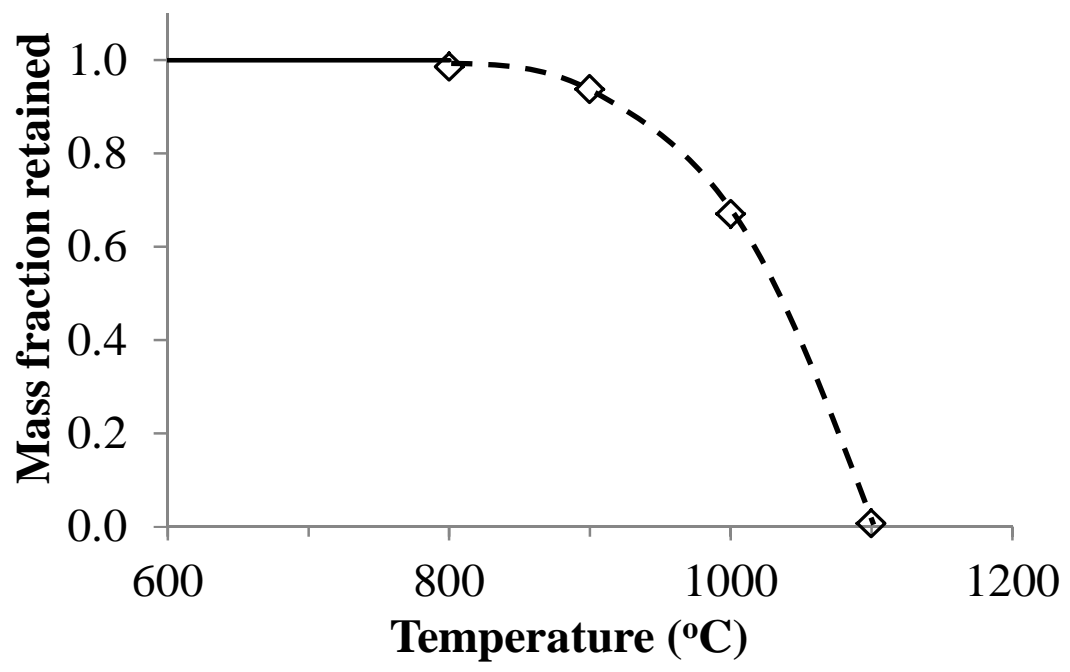

Fig. 8

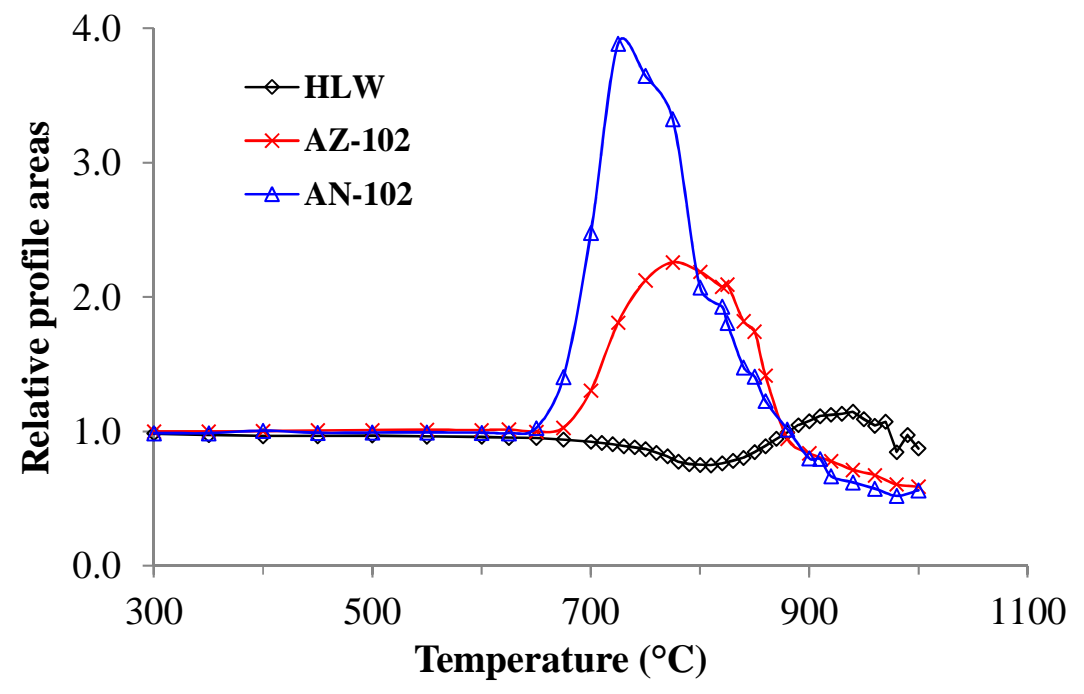

Fig. 9 